\title{
PENGEMBANGAN KETERAMPILAN WIRAUSAHA BAGI SANTRI PONDOK PESANTREN DI PONDOK PESANTREN MODERN AL-ITTIHAD
}

\author{
Bambang Hermanto' ${ }^{1}$, Syahril'²), Moh. Kurdi ${ }^{3}$ ) \\ 1),2),3) Universitas Wiraraja \\ ${ }^{1)}$ Email: bambangh@wiraraja.ac.id \\ ${ }^{2)}$ Email: syahril@wiraraja.ac.id \\ ${ }^{3)}$ Email: mkurdi@wiraraja.ac.id
}

\begin{abstract}
Abstrak
Selain pendidikan formal yang diwajibkan kepada santri, mereka juga diberikan pelatihan keterampilan seperti melukis, kaligrafi, dan pengolahan makanan. Meskipun dalam keadaan terbatas sarana dan prasarana yang tersedia, semangat pengurus pondok dan santri sangat tinggi dalam mengembangkan potensi diri, baik keterampilan seni maupun keterampilan pengolahan makanan dari bahan baku ikan. Dengan keadaan bahan baku yang sangat melimpah karena terletak di daerah kepulauan, hal sangat memudahkan untuk melakukan kegiatan pengolahan ikan. Setiap orang maupun lembaga didunia ini tidak ada yang bisa sendiri baik untuk memenuhi kebutuhan sehari maupun keperluan yang lain. Oleh karena itu, perlu adanya jalinan kerjasama dengan lembaga lain baik dari segi pendidikan maupun untuk meningkatkan kemandirian, kesejahteraan dan pemenuhan kebutuhan. Dengan masih menggunakan cara pengolahan ikan yang masih sangat sederhana, maka diperlukan penanganan, pengetahuan dan terknologi yang baik. Maka perlu adanya pelatihan kewirausahaan dan pengolahan bagi santri. Dengan memanfaatkan teknologi modern pengolahan ikan dan pemberian pelatihan kepada santri sampai pada proses pemasaran, diharapkan mantu memberikan nilai tambah dan membantu kegiatan lebih optimal, dengan harapan dapat meningkatkan pertumbuhan ekonomi masyarakat secara luas. Selain itu, untuk miningkatkan harga jual dan daya simpan. Kegiatan Pelatihan Kewirausahaan bagi Santri Yayasan Pondok Pesantren Modern Al-Ittihad secara umum berlangsung dengan baik, hal ini ditunjukkan dengan tumbuhnya spirit, motivasi, dan kreativitas mahasiswa yang menjadi santri di Yayasan Pondok Pesantren Modern Al-Ittihad untuk menggali ide potensi usaha serta dapat menyusun business plan usaha baru yang akan dikembangkan oleh mahasiswa yang menjadi santri di Yayasan Pondok Pesantren Modern Al-Ittihad
\end{abstract}

Kata Kunci: Wirausaha, Pondok Pesantren, Pengolahan Ikan

\section{Pendahuluan}

Dalam perkembangan teknologi dan ilmu pengetahuan, pondok pesantren dituntut mampu beradaptasi dengan segala perubahan yang ada. Para siswa (santri) harus dibekali dengan berbagai kemampuan yang tentunya sesuai dengan perkembangan zaman tanpa harus membuang sistem pendidikan klasik yang menjadi ciri khas pesantren.Sistem pendidikan pesantren terbukti ampuh dalam sejarahnya sebagai sistem pendidikan yang mampu memerdekakan santrinya dari ketergantungan pada orang lain.

Ciri khas pesantren adalah pengajaran tentang kemandirian kepada semua santrinya. Kemandirian juga merupakan penanaman awal dari pendidikan kewirausahaan di pondok pesantren. Kemandirian ini menjadi 
senjata dan modal penting bagi santri untuk membangun ekonomi umat yang masih tertinggal dari umat-umat lain.Ketertinggalan umat Islam dalam bidang ekonomi harus menjadi titik tolak bagi pondok pesantren untuk mendidik santrinya menjadi pengusaha.

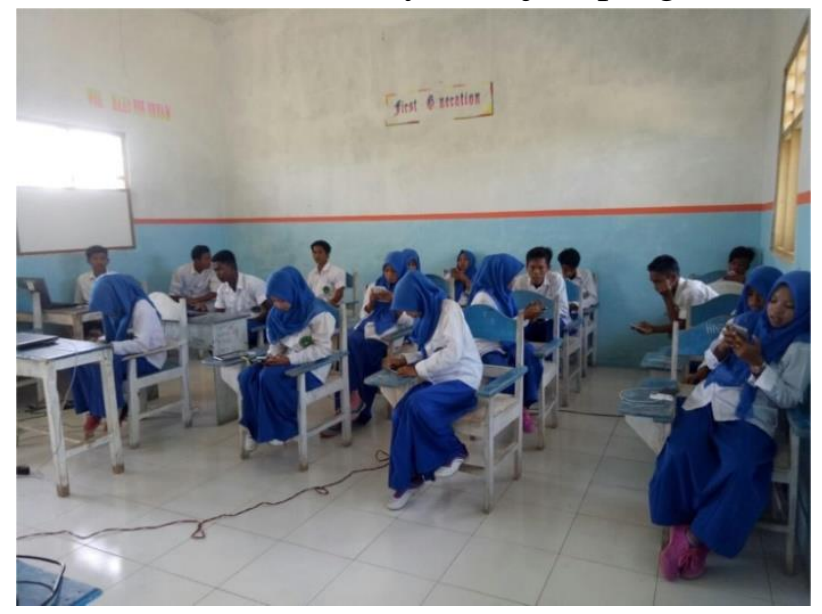

Gambar 1. Suasana belajar

Tabir kewirausahaan di pesantren harus dibuka selebar-lebarnya dengan meneladani semangat Nabi Muhammad SAW dalam berbisnis. Institusi pesantren harus menunjukkan kepada dunia bahwa para alumninya mampu berkontribusi bagi kemajuan bangsa dan negara.

Selain mendidik santri dengan pengetahuan agama dan umum, pesantren juga perlu mebekali para santrinya dengan pendidikan kewirausahaan sebagai salah satu langkah untuk mencetak santri memiliki mental dan kemandirian secara ekonomi.

"Alumni pondok pesantren punya kesempatan yang sama dengan alumni sekolah unggulan. Yang membedakan adalah kerja keras, ketekunan dan kesungguhan meraih cita-cita," kata Ketua MPR RI Zulkifli Hasan dalam keterangannya, Senin (1/5/2017/https://nusantara.rmol.co).

Pengembangan keterampilan para santri tentang kewirausahaan harus ditanamkan sejak dini, dengan memotivasi kemauan dan pengetahuan kewirausahaan terhadap para santri. Pengetahuan kewirausahaan menjadi sangat penting untuk kemandiri nanti jika sudah keluar dari pondok bahkan ketika masih berada di pondok pesantren.

Yayasan Pondok Pesantren Modern AlIttihad terletak di salah satu desa kepulauan yang ada di Kabupaten Sumenep, yaitu Desa Ketupat Pulau Ra'as. Sebagaimana Yayasan Pondok pesantren untuk memenuhi kebutuhan dana operasioanl masih bergantung pada donatur.

Selain pendidikan formal yang diwajibkan kepada santri, mereka juga diberikan pelatihan keterampilan seperti melukis, kaligrafi, dan pengolahan makanan. Meskipun dalam keadaan terbatas sarana dan prasarana yang tersedia, semangat pengurus pondok dan santri sangat tinggi dalam mengembangkan potensi diri, baik keterampilan seni maupun keterampilan pengolahan makanan dari bahan baku ikan. Dengan keadaan bahan baku yang sangat melimpah karena terletak di daerah kepulauan, hal sangat memudahkan untuk melakukan kegiatan pengolahan ikan.

Setiap orang maupun lembaga didunia ini tidak ada yang bisa sendiri baik untuk memenuhi kebutuhan sehari maupun keperluan yang lain. Oleh karena itu, perlu adanya jalinan kerjasama dengan lembaga lain baik dari segi pendidikan maupun untuk meningkatkan kemandirian, kesejahteraan dan pemenuhan kebutuhan. Dengan masih menggunakan cara pengolahan ikan yang masih sangat sederhana, maka diperlukan penanganan, pengetahuan dan terknologi yang baik. Maka perlu adanya pelatihan kewirausahaan dan pengolahan bagi santri. Dengan memanfaatkan teknologi modern pengolahan ikan dan pemberian pelatihan kepada santri sampai pada proses pemasaran, diharapkan mantu memberikan nilai tambah dan membantu kegiatan lebih optimal, dengan harapan dapat 
meningkatkan pertumbuhan ekonomi masyarakat secara luas. Selain itu, untuk miningkatkan harga jual dan daya simpan.

Bahan baku ikan dapat dijadikan beberapa macam olahan ikan, seperti sosis, dendeng, nugget, dan abon ikan. Sosis merupakan olahan dengan cita rasa yang gurih. Proses pembuatan sosis sangatlah mudah dan tidak membutuhkan waktu yang sangat lama. Dendeng adalah jenis makanan setengah basah yang terbuat dari ikan maupung daging dengan bentuk lebar dan tipis yang dibubuhi bumbu dan kemudian dikeringkan. Nungget dengan bahan baku dasar ikan adalah hasil pengolahan ikan yang disajikan sebagai makanan pendamping atau sebagai lauk pauk yang sudah siap di sajikan. Dengan pengolahan bahan baku ikan menjadi nugget memiliki keuntungan, sebab duri ikan sudah dibuang dan yang digunakan hanyalah dagingnya saja. Sedangkan abon ikan merupakan jenis hasil pengolahan ikan yang diawetkan. Pada dasarnya abon mengandung gizi yang sangat baik dan bisa di konsumsi langsung atau dijadikan sebagai lauk pauk.

\section{Metode}

Dalam upaya memecahkan permasalah diatas, maka akan dilakukan solusi pemecahan masalah sebagai berikut;

a. Memberikan materi tentang pentingnya wirausaha

b. Memberikan materi tentang pentingnya pemasaran dan pengemasan produk yang sesuai dengan selera konsumen.

c. Melakukan pelatihan pengolahan bahan ikan sebagai alternative keterampilan bagi santri

Dalam pelaskanaan kegiatan PKM ini ada beberapa tahapan yang harus dilakukan :

a. Melakukan pemetaan terhadap kondisi Yayasan Pondok Pesantren Modern Al-
Ittihad dengan menggunakan analisa SWOT untuk memilih 30 santri yang berpeluang;

b. Melakukan sosialisasi di Yayasan Pondok Pesantren Modern Al-Ittihad tentang action plan yang harus dilakukan;

c. Melakukan pendidikan tentang pentingnya menanamkan jiwa kewirausahaan terhadapa santri

d. Pelsakanaan Pelatihan pengolahan ikan, pada tahap ini akan dilatih untuk mengenal teknologi proses pengolahan ikan, mulai dari teknik penyiapan bahan dan alat, proses pengolahan, teknik pengemasan sampai kepada perhitungan usaha;

e. Melakukan pendampingan untuk memperbaiki kelemahan-kelemahan Program yang telah dilakukan;

f. Melakukan evaluasi secara keselurahan dari kegiatan program;

g. Melakukan analisa manfaat dan hasil Program yang telah dilaksanakan.

\section{Hasil dan Pembahasan}

Pelaksanaan pengabdian kepada masyarakat yang dilakukan dalam bentuk pelatihan kewirausahaan bagi santri pada Yayasan Pondok Pesantren Modern Al-Ittihad ini dilaksanakan dari tanggal 10-13 Juni 2019. Tahap pertama yang diawali dengan pembukaan dan dilanjutkan pemberian materi oleh Bapak Syahril, SE., M.Ak. dengan materi "Menjadi Pengusaha itu Menyenangkan".

Penyampaian materi ini diikuti dengan sesi tanya jawab dimana pada sesi ini para peserta pelatihan mendapatkan kesempatan untuk berdiskusi langsung dengan pemateri. Para peserta terlihat antusias dan aktif mengajukan beberapa pertanyaan kepada pemateri. Pertanyaan-pertanyaan yang diajukan antara lain adalah seputar langkahlangkah awal mengembangkan wirausaha. 
Selanjutnya, materi kedua diberikan oleh Bapak Moh. Kurdi, SP., MM. dengan materi Achievement Motivation dan menumbuhkan serta Meningkatkan Kreativitas dan Inovasi tentang Mindset Entrepreneur. Sesi ini dilakukan kurang lebih selama satu jam. Sesi kedua ini diawali dengan permainan agar para peserta pelatihan tidak merasa jenuh. Materi yang disampaikan antara lain adalah tentang dan menumbuhkan serta Meningkatkan Kreativitas dan Inovasi tentang Mindset Entrepreneur. Pada setiap akhir sesi pemberian materi, peserta pelatihan diberi kesempatan berinteraksi dengan pemateri dengan mengajukan pertanyaan ataupun gagasan.

Sesi selanjutnya adalah pembagian kelompok untuk melakukan diskusi guna menyusun business plan. Selanjutnya para peserta pelatihan dikondisikan untuk membentuk kelompok yang beranggotakan 3 sampai dengan 4 orang. Masing-masing kelompok ini dipandu untuk merencanakan sebuah ide usaha yang selanjutnya dituangkan dalam bentuk business plan. Business plan yang telah disusun kemudian akan dipresentasikan pada sesi berikutnya.

Sesi diisi dengan diskusi mengenai business plan yang telah disusun oleh masingmasing kelompok. Kegiatan ini diawali dengan presentasi oleh masing-masing kelompok, kemudian peserta lainnya dipersilakan untuk mengajukan pertanyaan, kritik maupun saran untuk didiskusikan bersama. Selanjutnya, tim pengabdi juga memberikan masukan kepada kelompok presenter terkait dengan materi-materi yang dipresentasikan oleh masing-masing kelompok.

Kelompok-kelompok yang telah terbentuk diantara para peserta kemudian menyusun dan mendiskusikan business plan, selanjutnya masing-masing kelompok tersebut mempresentasikannya. Meskipun sebagian besar peserta pelatihan pada hari kedua tidak mengikuti pelatihan di hari pertama, namun demikian para peserta tetap dapat mengikuti setiap aktivitas tanpa kesulitan yang berarti. Hal ini terbukti dengan setiap kelompok yang terbentuk dapat mempresentasikan business plan kelompoknya masing-masing.

Sesi diskusi business plan didahului dengan presentasi masing-masing kelompok. Setiap kelompok dipersilakan untuk mempresentasikan gagasan usaha kreatifnya masing-masing, selanjutnya peserta lain diberi kesempatan untuk mendiskusikan hasil presentasi dengan mengajukan pertayaan, kritik, maupun masukan kepada kelompok penyaji. Setelah itu, tim pengabdi juga memberikan masukan terkait dengan business plan yang dipresentasikan.

Pada sesi ini terdapat 4 kelompok yang mempresentasikan business plan. Masingmasing kelompok menyajikan gagasan usaha yang berbeda-beda seperti gagasan membuat Stick Ikan, Ikan Sarden, Pentol dan Bakso Ikan,serta kerupuk ikan.

Masing-masing kelompok mendapatkan kesempatan yang sama, yaitu mempresentasikan business plan yang telah disusun, kemudian berdiskusi dengan peserta lainnya, dan selanjutnya mendapatkan masukan dari tim pengabdi. Pada akhir sesi dilakukan pembagian hadiah untuk kelompok favorit dan juga pembagian doorprize untuk para peserta. Rangkaian acara pelatihan kewirausahaan ini selesai dan ditutup pada jam 12.00 WIB.

Acara pengabdian kepada masyarakat secara umum telah berlangsung dengan baik. Hal tersebut dapat dicapai berkat dukungan dari pengurus dan pengelola pondok yang telah membantu di dalam koordinasi kegiatan, publikasi dan penyebaran undangan bagi para 
santri. Faktor pendukung lainnya adalah peserta yang mengikuti pelatihan memiliki minat dan ketertarikan di bidang wirausaha sehingga dalam mengikuti acara tersebut peserta terlihat kritis dan antusias.

Namun demikian, meskipun secara umum acara pelatihan dapat berjalan dengan lancar akan tetapi ada beberapa hal yang menghambat pelaksanaan tersebut. Diantaranya adalah peserta yang datang hanya sebanyak 25 orang dari jumlah total yang di undang sebanyak 30 orang santri. Hal ini dikarenakan banyaknya tugas dan kegiatan terkait pondok yang bersamaan dilaksanakan. Selain itu, beberapa peserta datang terlambat, sehingga acara terpaksa mundur dari jadwal yang telah ditentukan.

\section{Simpulan}

Kegiatan Pelatihan Kewirausahaan bagi Santri Yayasan Pondok Pesantren Modern AlIttihad secara umum berlangsung dengan baik, hal ini ditunjukkan dengan tumbuhnya spirit, motivasi, dan kreativitas mahasiswa yang menjadi santri di Yayasan Pondok Pesantren Modern Al-Ittihad untuk menggali ide potensi usaha serta dapat menyusun business plan usaha baru yang akan dikembangkan oleh mahasiswa yang menjadi santri di Yayasan Pondok Pesantren Modern Al-Ittihad.

\section{Daftar Pustaka}

Lisdiyana Fahrudin. 1998. Teknologi Tepat Guna Membuat Abon. Yogyakarta: Penerbit Kanisius. Cetakan ke 8

https://nusantara.rmol.co/read/2017/05/01/289

715/Santri-Juga-Perlu-Terapkan-Ilmu-

Kewirausahaan-

https://www.researchgate.net/publication/3144

92028_MEMBANGUN_MENTAL_KE

WIRAUSAHAAN_SANTRI_DI_POND
OK_PESANTREN_RIYADLUL_JANN AH_MOJ OKERTO 